\title{
Evaluation of Quality Management in Sports Club in Dubai
}

\author{
MOHAMED ABDULWAHAB ALANASARI \\ Dubai Sports Council. Development \& Corporate Excellence Office. Dubai. United Arab Emirates.
}

\author{
RIDHA SALLAOUI \\ Shabab Alahli Dubai Club - Dubai. United Arab Emirates. \\ Email: rida.sallaoui@laposte.net \\ Tel : 00971501154966
}

NIZAR SOUISSI

High Institute of Sport and Physical Education, Ksar-Saïd, Manouba University Tunisia.

\begin{abstract}
The quality management of the sports clubs is a decisive factor for the development of the organizations, therefore, it is essential to know their dimensions of being able to analyse it, knowing their parts and improving the efficiency and accuracy of the service. The aim is to carry out a diagnosis of the level of implementation of quality in the Sports Clubs of Dubai, UAE. The study questionnaire inspired by the European Foundation for Quality Management is divided into three parts, of which, each consists of a total of 26 items. This evaluation tool was tested in majority sports clubs in Dubai. The organizational culture and the atmosphere are typical assets of Dubai sports clubs, the strong point being led. The main weaknesses are the lack of cognitive awareness that some employees show in the field in terms of quality standards and programs.

Keywords: Management, Quality System, Leadership. Cognitive Awareness, Football.
\end{abstract}

\section{Introduction}

The concept of quality and quality management acquires an increasing important happening at the beginning from a mere control or inspection to become one of the mainstays in the strategies of public and private organizations. The Quality Management will permit separating and contending in another stage described by fast changes in supply and demand (Casadesús et al., 2010). It is a method for overseeing exercises to to gain productivity, adequacy and intensity, guaranteeing long haul probability for the association to subsist, addressing the necessities of its clients, representatives, investors and society as a rule (Zargar et al. 2011). Numerous researcher believe that Total Quality Management advances competitiveness by building up a constant change in the distinctive territories that make up the organization; both what we call internal quality, activities change (Mak 2011; Lee et al., 2009; Sila, 2007), and external quality or execution of firms (Powell, 1995; Kaynak, 2003).

Total Quality Management (TQM) is a management approach that seeks to obtain quality management through the participation of all organisational members, and by aiming at long-term success through customer satisfaction and benefits to all members of the organization and society. It is in excess of an administration theory; it can be viewed as an advantageous structure utilized as a part of and by associations to ensure a precise and lasting streamlining of the additional incentive with a specific end goal 
to expand the acknowledgement of their points. As a result of this proactive approach, all essential, supporting and administrative procedures must be outlined in a way that guarantees an ideal (saw) quality for clients, representatives and different partners.

Recent research underlined the need for total quality management in the sports sector (De Knop et al. 2004; De Knop \&Buisman, 1999; Van Bottenburg, van 't Hof \&Oldenboom, 1997; Coopers \& Lybrand, 1997). Sport is a business and any business that is well managed, brings development. One of the developmental programmes and ventures of any develop-conscious nation is sports. Orunaboka and Elendu (2009) characterized sports as any profoundly composed physical movement, which has its equipment, definite limits and guidelines made by an expert body.. Sports accrues fund to the society through its products and services. The developmental properties of sports may not be harnessed if not well managed and marketed using marketing tools. Financial resources required for developmental projects in the society could be generated through sports (Elendu, 2012). In modern times, developed and developing countries have continued to realize and utilize sports for their socioeconomic growth and development through the application of marketing principles, theories and tools. Marketing, according to Kotler (1997), is a social managerial process by which individuals and groups obtain what they need and want through creating, offering, and exchanging products of value with others.

Sports management is the application of all concepts, theories, principles, processes, practices and philosophy of management to sports situations, persons, institutions, and events in order to achieve sports goals. Elendu (2012) viewed sports development as a positive improvement and change in the status of sports facilities and equipment, sports organization and administration, welfare of sports personnel, officiating officials, athletes, spectators, and fans irrespective of one's sex, age, religion, race, ethnicity, and economic status, to the realization of sports goals in a given society. The quality of the sports service is a decisive factor for the development of the organizations (Zeithaml et al., 1985). Since the sector has evolved into a differentiated buyers' market, with service and quality as the most critical success factors, the need for professionalization has increased considerably. Moreover, sports clubs are faced with substantial challenges, such as financial and infrastructural problems, dropout, and a shortage of board members and coaches (De Knop et al 2004).

Hasan Al- Shaf'i (2006) argues that investing in sports institutions means increasing its capital, It paves way for mutual interest relationships between investors and the institutions represented by the players, the management and the audience. By engaging marketing in sports institutions, the country can restructure its plan designed to support them by following the policy of sponsoring. This can be significantly beneficial to regain balance in these institutions empowering them to achieve their goals and increase the variety of activities. Al-Shaf'i also believes that Total Quality Management in sports institutions requires both the senior and the executive management to ensure that their employees show the right attitudes towards quality systems. They also need to provide for the essential resources, whether material or human, let alone ensuring the integrity and the correctness of the records, controlling the operations of all activities, and using effective systems to achieve their objectives.

The continuity, growth and development of the activities of any sports institution are linked to its ability to attract as many clients as possible and satisfy their needs, which essentially depends on the level of the services it provides. Nowadays, developed countries have started to consider the significant role of investment in developing sports. To such countries, investment is an essential and urgent need which they are obliged to provide their citizens with. It is necessary for technical conduction any sports program and building a fully developed basis for sports. In these countries, sports institutions can attract the private sector represented by official sponsors by means of marketing and advertising their products and services in the sports sector. Furthermore, they can benefit from their expertise to manage effective investment and create new horizons for knowledge and professionalism in order to develop sports and facilities new encouraging environments that welcome any potential development. 
The FIFA president, Gianni Infantino, (2016) admitted a model of modern leadership who enjoys a high level of awareness and knowledge about the methods and the mechanisms used in management in the field of sport, calls the attention to the modern experience in the fields of quality and international football arbitration, being essential for any union, whether international or continental, to succeed. Quality and international football arbitration are important for managing the structures of these institutions in a professional and unbiased way by means of establishing reformations, especially after the dark phases called "Arbitration crisis within FIFA". In doing so, FIFA has attempted to go back to the basic concepts of arbitration, such as transparency, prejudice, quality, sustainability, monitoring, and fieldwork. He also affirms that the development of quality systems in FIFA requires the implementation of arbitration principles pursuant to international standards led by a new competent team consisting of the board of directors, the general secretariat, permanent committees, a development committee, the finance committee half of its members are independent, an external committee half of its members are independent to work on updating, revising, and executing the rules and the regulations in a transparent and unbiased way. All of these entities are working hand in hand following a new strategy in which all efforts should be exerted to develop. In addition, he urges to form a new judicial body appointed to implement all the new provisions for the protection of human rights. Dubai Sports Council, founded in November of 2005 by virtue of a decree issued as per UAE Vice- President, Prime Minister, Dubai Ruler H.H. Sheikh Mohammed Bin Rashid Al Maktoum, who charged the Council to develop sports in Dubai and promote the culture of professional sports, creates an integrated environment for sports in order to meet the demands of the society and sharpen cultural as well as physical talents of the youth to be channelled to international competitions. The H.H. Prince is committed to develop the activities of sports clubs and shift them from being disorganized and volunteering-based to be more systematic and law-based. To accelerate the process of change and guarantee its continuity and sustainability, he urges to follow the modern concepts of quality management. In doing so, he launched one of the initiatives called "Quality Week of Dubai Sports Clubs" in 2013 under the slogan "Right First Time". This initiative is a part of the Council's strategic plan of (2011-2016), through which the council dedicates a week annually for the purpose of developing and promoting quality and excellence at the institutions, football clubs and companies to enhance ties and corporation among them. Thus, methods of institutional work are developed and are made inspirational for many sports institutions and bodies. As a result, Dubai clubs have started to gradually follow the dynamic processes of improvement and development.

\section{The Sports Clubs and Football Companies in Dubai as a Case Study}

After scrutinizing the status, institutional structures and the employees of sport institutions in Dubai, the researcher, who has a direct contact with these institutions, has found out that such institutions, having been established in simple social environments based on mutual trust, sacrifice and voluntary efforts, lacks administrative systems that monitor and put relationships within clear frames. All the work done in these institutions is based on experience accumulated over the years. Consequently, quality systems are barely implemented there. And change sounds difficult there, because change means moving from the circle of unquestioned voluntary work out to organize work measured by the evaluation of performances and achievements. The study problem can be summed up in the following questions:

This article focuses on management practice in sports clubs and the methodology that has been developed to introduce the principles of service and quality management in these particular organizations. The aim is to evaluate and carry out a diagnosis of the level of implementation of quality management in the Sports Club of Dubai.

\section{Concepts and Terms}

The study involves a range of terms associated with quality such as quality control, quality improvement and quality assurance. In order to help scholars and researchers get a better understanding in the field, the following is an attempt to present each of these terms in a simpler way. 


\section{Quality}

It refers to the extent to which all requirements expected or determined by the clients are met (National Quality Assurance and Accreditation Committee, 2004).

\section{Quality Improvement}

It refers to the systematic and organized approach to selectively determine the available opportunities to improve products or services. It aims to reduce violation of the desired standards and achieve the quality gap to guarantee the consistency of the process and control the results. (Khoja, 2004).

\section{Quality Management System}

It refers to the establishment of policies and goals geared toward managing and controlling quality at the institutions. (National Quality Assurance and Accreditation Committee, 2004).

\section{Total Quality Management}

Witcher (1990) divides total quality management into three subconcepts: "total", which takes every individual at the institutions, including the clients and the service receivers as responsible for achieving quality; "quality", which refers to fully achieving clients' needs; and "management", which refers to the commitment of both the senior and executive administrations to meet quality levels.

\section{Study Literature}

Amid the most recent decades, diverse executes have seemed to endeavor to assess the quality, both the apparent (subjective) and the goal. The investigation might be quantitative or subjective, both inside and outer to the association. Yet there are few studies of the service quality and user satisfaction of sports entities in the literature related to sport management (Tsitskari et al., 2006). There are studies on the service quality of sport entities services focused on the evaluation of expectations, satisfaction and perceptions of quality by users, using some scales: QUESC (Quality Excellence of Sports Centres) (Kim and Kim 1995); NEPTUNO 1 (Luna et al., 1998), FITSSQ (Fitness and Sport Service Quality) (Papadimitriou and Karteroliotis,2000); inventario de Calidad en Programas de ActividadFísica (I.C.P.A.F.), (Hernández 2001); SERVQUAL (Barrera and Reyes 2003; Calabuig et al., 2010; Dorado and Gallardo 2003; Mañas Giménez et al., 2008; Morales Sánchez et al. 2004; Morales et al., 2005; Morales et al., 2009; Morales Sánchez, 2003; Salvador, 2005) QSport-10 (Rial-Boubeta et al., 2010), and more recently the DEPQUAL scale (Salazar, 2015) that measures the quality perceived by athletes and others in events and sports facilities, most of them with little market penetration. Different approaches to analyze the management of municipalities have been used in other studies, some through the analysis of municipal sports policies and its evaluation (Redondo, 1997), others analysing its functions and manifestations in management (Martínez del Castillo, 1994) and analyzing user satisfaction (Dorado, 2006).

In recent years, emerging models and tools that seek to assess the quality of the organization, examining the processes and everything associated with them. The dimensions are transformed into principles which are joined with the benefits associated with revenue, cost reduction, increase in staff morale and a welldocumented (Robinson, 2002). Authors like Marques (2003), Ruiz (2001), in the Institute of Sports City of Seville or Correal (2003), in the Patronato Municipal de Benalmádena Sport, understand that the dimensionality offered by the International Organization for Standardization (ISO) can help us achieve goals that allow us to improve the quality. In this sense, Marques (2003), considered appropriate ISO assessed quantitative indicators, qualitative and own service. Quesada and Diez (2002), observed that the quality of sports services is broken down into a series of sub-models (subjective and objective). These would be the formal quality, relational quality, environmental quality and quality technology. 
In Europe It has been opted for the application Foundation for Quality Management (EFQM) of Excellence Model, contextualized to the field of sports services with the questionnaire of Quality Municipal Services (SERMUCAL) Martínez-Moreno et al. (2006) that offers to SDM, a practical tool to address evaluation systems and measurement in its path to excellence, helping them to understand their shortcomings and to stimulate the search for solutions. It helps to analyze and evaluate an organization in each of the key aspects: (a) to identify its strengths and areas for improvement, (b) to establish a level of excellence (score) in each of the key aspects, (c) to establish priorities on where to act. There is a clear predominance of the use of this model in countries with the disparate structure of markets and institutional environment, such as UK, Spain, Germany, Italy and Turkey (Allur 2010).

This is the case of Pardo (2003) in sporting entities. Mestre (2004), Galan (2004) at the University of Seville. Redondo(1997), Redondo and al. (2006), trying to convey administrations to EFQM sports city, in schools, is important to adjust it to the general organisation. Giner (2006) with its "Administration by Commitment", received the criteria of the EFQM in the City of Esplugues de Llobregat. Indeed, surveys, for example, profile v4.0. progressed or associations like Euskalit.

Games England (2004), additionally takes after the structure of the EFQM, utilizing the Towards an Excellence Service (TAES) thinking about the accompanying measurements: administration, arrangement and methodology, group get, the working of society, utilization of the standard of authority and administration estimation and comprehension of the task. Total quality management has grown into a common term in the jargon of modern management.

It has also become one of the successful methods followed in various institutions, whether public or private. To keep pace with the new changes posed by globalization and information revolution, total quality management has been an integral part of the global economic system. It is a symptom of globalization, which has been the interest of many leaders and scholars in various fields. To implement total quality management in sports institutions, it has become a must to recognize the obstacles to it. It is worth noting that the success of the management can only be achieved by the individuals spotting and challenging these obstacles and trying to avoid them. Hence, to cope with the scientific and technological advances, it has been essential for sports institutions to challenge the changes and solve them. This has urged the researcher to spot, group, understand and evaluate the level of implementation of quality management in clubs and other sports institutions in Dubai.

\section{Methodology}

This study is conducted using qualitative methods based on data collection and the scientific description of the study problem. The researcher conducts a survey on the available literature related to the subject matter to design the framework and answer all the questions related to the obstacles to the implementation of the systems of quality management in football clubs and companies in Dubai in UAE, test the pre-set hypotheses, and statistically identify the relationships among the variables.

\section{The Study Sample and Population}

The population of the study includes all the employees of football clubs and companies, namely (1046), as documented in records. The stratified random method was used in sampling. The sample was further subdivided into strata and categories based on demographical and personal factors. 210 questionnaires were given to the population. Out of the total handed questionnaires, 200 ones, namely (95.2\%). 17\% of the questionnaires, namely $4.8 \%$, proved invalid and were excluded. Accordingly, 183 questionnaires, namely $(87.1 \%)$ out of the total number of the questionnaires, proved valid for analysis. Table 1 and 2 illustrate the distribution of the sample. 
Table 1. Sampling Associated with Demographical and Occupational Factors based on the Variables of Gender, Qualification, Age, Occupation, Years of Experience, and Employer

\begin{tabular}{|c|c|c|c|}
\hline Variable & Level of Education & Number & $\begin{array}{c}\text { Percentage } \\
(\%)\end{array}$ \\
\hline \multirow[t]{2}{*}{ Gender } & Males & 142 & 77.6 \\
\hline & Females & 41 & 22.4 \\
\hline \multirow[t]{4}{*}{ Qualification } & Below High School & 9 & 4.9 \\
\hline & High school & 64 & 35.0 \\
\hline & Graduate & 100 & 54.6 \\
\hline & Post-graduate studies & 10 & 5.5 \\
\hline \multirow[t]{4}{*}{ Age } & Under 30 years old & 32 & 17.5 \\
\hline & $30-39$ years old & 85 & 46.4 \\
\hline & $40-49$ years old & 50 & 27.3 \\
\hline & more than 50 years old & 16 & 8.8 \\
\hline \multirow[t]{3}{*}{ Occupation } & Administrative staff & 116 & 63.4 \\
\hline & Technicians & 59 & 32.2 \\
\hline & Medical staff & 8 & 4.4 \\
\hline \multirow[t]{4}{*}{ Years of Experience } & Less than a year & 5 & 2.7 \\
\hline & $1-3$ years & 29 & 15.9 \\
\hline & $4-7$ years & 63 & 34.4 \\
\hline & More than 8 years & 86 & 47.0 \\
\hline \multirow{2}{*}{ Employer } & Club & 120 & .65 .6 \\
\hline & Company & 63 & 34.4 \\
\hline
\end{tabular}

Table 2. The distribution of the sample based on employers

\begin{tabular}{|lcc|}
\hline Club & Frequency & Percentage $(\%)$ \\
\hline Al Shabab & 39 & 21.31 \\
Al Wasl & 27 & 14.75 \\
Al Nasr & 26 & 14.21 \\
Al Ahli & 22 & 12.02 \\
Dubai Chess Club & 21 & 11.48 \\
Dubai Club of Persons with Disability (People of Determinations) & 20 & 10.93 \\
Hatta & 15 & 8.20 \\
Dubai & 13 & 7.10 \\
Total & 183 & 100 \\
\hline
\end{tabular}

\section{Research Variables}

The study questionnaire is designed based on the framework and the related literature in the field. The questionnaires inspired by the European Foundation for Quality Management (EFQM 2010) are divided into three parts, each consists of a total of 26 items, of which seven are socio-demographic (i.e. Club, gender, age, educational qualifications, completed studies, job title or position performed, group and level, employment status, functions performed and seniority in the Club). The remaining items are closed answers with a Likert scale ranging from 1 Nothing or very little, to 3: (always representing 3 points), (sometimes representing 2 points), (almost never representing 1 point). Being distributed as follows: Criterion (1) Leadership (3 items), (2) Policy and Strategy (3items), (3) People management (3 items), (4) Alliances and Resources (3 items), (5) Processes (11 items). Measuring the paragraphs is calculated as follows: As for the means, they are categorized as follows: less than (1.67) significantly indicates a low level, (1.67 - 2.33) significantly indicates moderate level, and (2.34 - 3) significantly indicates high level. 


\section{The Validity of the Study Tool}

The committee members, 7 competent individuals, were referred to check the validity of the paragraphs of the questionnaire. Based on their comments, some paragraphs were redesigned and the required changes were made to fit the content of the paragraphs. Moreover, in order to test the degree of the employees' willingness to respond to the questionnaire, it was handed into voluntary- response sample of 27 employees, surely not included in the main sample, and they showed no reluctance to respond.

\section{The Reliability of the Study Tool}

The reliability of the tool was confirmed using the method of (test-retest) by distributing the questionnaire to a pilot sample of (25) individuals not included in the main sample two weeks before distributing the questionnaires to the main sample. The reliability coefficient of the study tool was $(0.78 \%)$, calculated by using Cronbach's Alpha, which was $(0.85 \%)$. Table 3 below illustrates the results:

Table 3. Reliability Coefficients of Internal Consistency for the tool as a whole and for each implication

\begin{tabular}{|c|c|c|c|c|}
\hline \multicolumn{5}{|c|}{ separately } \\
\hline No & Implications & Chronological & Reliability C & \\
\hline & & $\begin{array}{l}\text { order of the } \\
\text { paragraph }\end{array}$ & Test- retest & Alpha \\
\hline 1. & $\begin{array}{l}\text { an overview of the application of quality in } \\
\text { the institution }\end{array}$ & $3-1$ & 0.83 & 0.90 \\
\hline 2. & the commitment of the management & $6-4$ & 0.81 & 0.87 \\
\hline 3. & Financial resources & $9-7$ & 0.75 & 0.83 \\
\hline 4. & cognitive awareness & $15-10$ & 0.76 & 0.85 \\
\hline 5. & Participation and empowerment & $18-16$ & 0.71 & 0.80 \\
\hline & 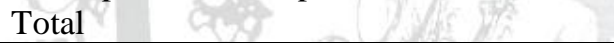 & $1-18$ & 0.78 & 0.85 \\
\hline
\end{tabular}

Table 3 indicates that reliability coefficients for quality applications range from $(0.71)$ to $(0.83)$ relating to test-retest, and the total are (0.78). Referring to the results of Alpha test, reliability coefficients range from $(0.83)$ to $(0.90)$, and the total is $(0.85)$. The total average of both tests is $(0.81)$. These values are considered acceptable for the purposes of the study, taking into consideration that the acceptable internal consistency is 0.60 and above.

\section{Statistical Analysis}

SPSS.16 was used to analyze the data represented by the employees' answers in the designed questionnaire and the hypotheses were tested according to the following statistical operations:

1. Calculating the frequencies and the percentage to describe the characteristics of the chosen sample, the mean, and the standard deviations of the responses.

2. Calculating multiple regressions to test the validity of the questionnaire, the independent variable and its significance to the dependent variable and its implications.

3. One-way analysis of variance (ANOVA) to compare the differences in the sample responses based on the demographics variable as for the dependent variable.

4. Cronbach's Alpha to measure the internal consistency of the study implications. 


\section{Results}

Table 4. The results of the degree of the management's commitment to implementing quality standards in football clubs and companies.

\begin{tabular}{|lllllc|}
\hline $\begin{array}{l}\text { Paragraph } \\
\text { No. }\end{array}$ & Paragraph mean & $\begin{array}{l}\text { Standard } \\
\text { deviation }\end{array}$ & Rank & Level \\
\hline 4 & $\begin{array}{l}\text { The management of the club/company } \\
\text { is aware of the concepts and the } \\
\text { applications of quality } 2.86\end{array}$ & 0.98 & 1 & High \\
$\begin{array}{l}\text { The management of the club/company } \\
\text { supports and encourages its } \\
\text { employees ideas and initiatives } \\
\text { contributing to promote and develop } \\
\text { the concepts of quality } \\
\text { The management of the club/company } \\
\text { shows interest in implementing } \\
\text { quality projects and programs as a } 1.65\end{array}$ & 0.094 & 3 & High \\
part of the work plan \\
Total average
\end{tabular}

Based on the Table 4, the total average of the sample's responses about the management's commitment to implement quality standards in football clubs and companies are high; the total mean is (2.45); and the standard deviation (0.96). Paragraph No. (4), "the management of the club/company is aware of the concepts and the applications of quality", ranks the first at a mean of (2.86); followed by paragraph No. (5), "the management of the club/company supports and encourages its employees' ideas and initiatives contributing to promote and develop the concepts of quality", at a mean of (2.76); and paragraph No.(6), the management of the club/company shows interest in implementing quality projects and programs as a part of the work plan, comes the last at a mean of (1.65).

Table 5.Results of the level of the employees'cognitive awareness of quality standards in football clubs and companies.

\begin{tabular}{|c|c|c|c|c|c|}
\hline No. & Paragraph & mean & $\begin{array}{l}\text { Standard } \\
\text { deviation }\end{array}$ & Rank & Level \\
\hline 10 & $\begin{array}{l}\text { The management of the club/company runs programs to } \\
\text { promote and implement quality concepts and applications } \\
\text { as a part of the operating plan }\end{array}$ & 2.84 & 0.98 & 1 & High \\
\hline 11 & $\begin{array}{l}\text { The management of the club/company supports } \\
\text { encourages, and adopt programs for promoting quality } \\
\text { concepts and applications }\end{array}$ & 2.82 & 0.97 & 2 & high \\
\hline 12 & $\begin{array}{l}\text { Employees of the club/company are committed to } \\
\text { implementing programs and initiatives developing a } \\
\text { quality system }\end{array}$ & 1.64 & 1.02 & 3 & Moderate \\
\hline 13 & $\begin{array}{l}\text { I know about the basic concepts and applications of } \\
\text { quality }\end{array}$ & 1.62 & 1.03 & 4 & Moderate \\
\hline 14 & $\begin{array}{l}\text { Employees know about the concepts and applications of } \\
\text { quality }\end{array}$ & 1.60 & 1.04 & 5 & Moderate \\
\hline 15 & $\begin{array}{l}\text { Employees don't know about the concepts of quality } \\
\text { Total Average }\end{array}$ & $\begin{array}{l}1.58 \\
2.01\end{array}$ & $\begin{array}{l}1.06 \\
1.01\end{array}$ & $\begin{array}{l}6 \\
-\end{array}$ & $\begin{array}{l}\text { Moderate } \\
\text { High }\end{array}$ \\
\hline
\end{tabular}

According to the Table 5, the total average of the sample's responses about the level of the employees' cognitive awareness of quality standards in football clubs and companies is high, at a mean of (2.01) and a 
standard deviation of (1.01). Paragraph No.10, "the management of the club/company runs programs to promote and implement quality concepts and applications as a part of the operating plan", ranks the first at a mean of (2.84); followed by paragraph No. 11, "The management of the club/company supports, encourages, and adopt programs for promoting quality concepts and applications", at a mean of (2.82); then comes paragraph No.12, "Employees of the club/company are committed to implementing programs and initiatives developing quality system", the third at a mean of (1.64); followed by paragraph No. 13, "I know about the basic concepts and applications of quality" at a mean of (1.62); then comes paragraph No.14," Employees know about the concepts and applications of quality" at a mean of (1.60); then paragraph No.15, "Employees don't know about the concepts of quality", comes the last.

\section{Discussion}

Results show that the total average of the sample responses concerning the commitment to implementing quality standards is high at a mean of (3.75) and the standard deviation of (0.96). Paragraph No.4, concerning the management's awareness of quality concepts and applications, ranks the first and we found a transformational leadership in majority Clubs. This explained the fact that sports management is now aware that to join the competitive market, whether in the field of football investments or in the field of advanced sports competitions, they need to implement the latest quality concepts, programs and standards. To be one of the tops, updating the knowledge of quality has become a must.

The Bass et al. (2003) isolates transformational initiative into four regions which grasp: Idealized influence, Inspirational motivation, Intellectual stimulation and Individualized consideration. Romanticized impact; implies making a glorious image alongside significant and self-assurance based regard in the nearness of workers.

Persuasive inspiration; alludes to pioneers that draw a strict and positive perspective of future for their subordinates and stimulate them to go toward authoritative points and boss missions. Intellectual incitement; in this way, pioneer accentuates on completing creativity and innovation and utilizing novel courses in doing works. Individualized thought; this measurement speaks to the leaders claim consideration regarding subordinates and treating them in the best course.

The average of the results concerning the cognitive awareness of quality standards is moderate at a mean of (3.68) and a standard deviation of (1.01). Paragraph No.10 inquiring about the management efforts to run programs for promoting quality standards and applications as a part of the operating plan ranks the first.

The results also show that the management supports and encourages programs for promoting quality concepts and applications and that the employees are committed to implementing projects and initiatives to develop quality system. These results indicate that today's management of football clubs and companies seek to implement quality concepts to raise the levels of their employees, boost their productivity and get the best results. Keeping pace with today's changes in the field of knowledge helps promote football clubs and companies.

\section{Conclusion}

The project on the quality in clubs in Dubai represents remarkable progress in the UAE to introduce quality (management) in sports and all necessary measures have been undertaken in order to implement this system. Together with other club supporting projects. However, for it to be effective, it must continue in this way. To achieve that end, all Dubai sports Clubs involved in this project received and get an additional subsidy from the DSC for quality related projects. In the future, subsidies might be divided among clubs on the basis of (some standards of) DSC. 


\section{References}

Allur E. (2010). The dissemination of the EFQM self-evaluation model across Europe. Rev Int Comp Manag 11(5):971-979

Barrera R, Reyes MC. (2003). Análisis comparado de las escalas de medición de la calidad de servicio. In: Jornadas XIII (ed) Hispano-Lusas de Gestión Científica, 13. Universidad de Santiago de Compostela, Lugo, pp 285-294

Bass, B. M., Avolio, B. J., Jung, D. I., \& Berson, Y. (2003). Prediction unit performance by assessing transformational and transactional leadership. Journal of Applied Psychology, 88(2), 207-218. http://dx.doi.org/10.1037/0021-9010.88.2.207

Calabuig F, Burillo P, Crespo J, Mundina J, Gallardo L. (2010). Satisfacción, calidad y valor percibido en espectadores de atletismo. Revista Internacional de Medicina y Ciencias de la Actividad Física y el Deporte 10(40):577-593Coopers \& Lybrand, 1997)

Casadesús M, Marimon F, Alonso M (2010) The future of standardised quality management in tourism: evidence from the Spanish tourist sector. Serv Ind J 30(14):2457-2474

Correal J. (2003) Implantación del modelo de aseguramiento de la calidad ISO 9000:2000 en el Patronato Deportivo Municipal de Benalmádena. In Instituto Andaluz del Deporte (Ed.), La gestión de la calidad de las entidades deportivas como un reto de futuro. Málaga: Instituto Andaluz del Deporte. 2003

De Kno P, VanHoecke, VeerleDe Bosscher. (2004). Quality Management in Sports Clubs Sport Management Review Volume 7, Issue 1, , Pages 57-77

Dorado A. (2006). Análisis de la satisfacción de los usuarios: Hacia un nuevo modelo de gestión basado en la calidad para los servicios deportivos municipales. Consejo Económico y social de Castilla-La Mancha, Toledo

Dorado A, Gallardo L. (2003). La incidencia en la valoración de la calidad de un servicio deportivo en función de los factores que determinan la prestación del mismo. En Las Ciencias de La Actividad Física y el Deporte en el Marco de la Convergencia Europea" en actas del III Congreso de la Asociación Española de Ciencias del Deporte. Valencia, Asociación Española de Ciencias del Deporte. Recuperado de http//www.unex.es/eweb/cienciadeporte/congres/04\%20val/pdf/c.162.pdf [fecha de consulta:marzo de 2008] (EFQM 2010)

Elendu, I. C. (2012). Nigeria's debased values system at the modern era: Implications for sports development. Journal of Education and Practice, 3(3), 48 - 53.

Gianni Infantino. (2006). FIFA (https://ar.fifa.com/)

Galán M. (2004). Informe de la evaluación externa del Servicio de Actividades Deportivas de la Universidad de Sevilla. Recuperado de: http/www.us.es/sadus/documento/INFORME_EVAL_SADUS.pdf

Giner E. (2006). Compromisos de servicio con los ciudadanos. XI Congreso Internacional

CLAD sobre la Reforma del Estado y de la Administración Pública, Ciudad de

Guatemala, Guatemala. 2006.

Hernández A. (2001). Un cuestionario para evaluar la calidad en programas de Actividad Física. Revista de Psicología del Deporte 10(2):179-196

Kaynak H. (2003). The relationship between total quality management practices and their effects on firm performance. J Oper Manag 21(4):405-435Kotler (1997),

Kim D, Kim SY. (1995). QUESC: an instrument for assessing the service quality of sport centres in Korea. J Sport Manag 9:208-220.

Khoja, T. (2004). An Introduction to Improving the Quality of Health Services: Preliminary Health Care. The Executive Office of the Councils of Ministers of Health of Gulf Cooperation Council for the Arab States, Suadi Arabia.

Kotler, P. (1997). Marketing management - Analysis, planning, implementation, and control. (9th ed.) New Jersey: Prentice-Hall

Lee PKC, To WM, Yu BTW. (2009). The implementation and performance outcomes of ISO 9000 in service organizations: an empirical taxonomy. Int J Qual Reliab Manag 26:646-662Likewise

Luna R, Mundina J, Gómez A. (1998). La creación de una escala para medir la calidad de servicio y la 
satisfacción: el Neptuno-1. En J. Martínez de Castillo, (comp.): Deporte y Calidad de Vida, Madrid: Librerías deportivas Esteban Sanz, pp 279-290

Giner E. (2006). Compromisos de servicio con los ciudadanos. XI Congreso Internacional CLAD sobre la Reforma del Estado y de la Administración Pública, Ciudad de Guatemala, Guatemala..

Mak BLM. (2011). ISO certification in the tour operator sector. Int J Contemp Hosp Manag23:115-130

Mañas MA, Giménez G, Muyor JM, Martínez V, Moliner CP. (2008). Los tangibles como predictores de la satisfacción del usuario en servicios deportivos. Psicothema 20(2):243-248

Martínez del Castillo J. (1994). Un Modelo de Planificación en las Organizaciones Deportivas Municipales. Revista Española de Educación Física y Deportes 1(1):27-34

Martínez-Moreno A, López MA, López JM. (2006). Planificación de la calidad en Actividad Física. Granada: Servicio de Publicaciones. Universidad de Murcia. Instituto Propio de Ciencias del Deporte

Marques L. (2003). El aseguramiento de la calidad en la gestión de entidades deportivas: Las

normas ISO 9000:2000. In Instituto Andaluz del Deporte (Ed.), La gestión de la calidad

de las entidades deportivas como un reto de futuro (pp. 1-18). Málaga: IAD.

Mestre JA. (2004). Estrategias de gestión deportiva local. Barcelona, España: Inde.

Morales Sánchez V. (2003). Evaluación psicosocial de la calidad en servicios municipales deportivos: aportaciones desde el análisis de variabilidad. SPICUM, Málaga

Morales Sánchez V, Blanco Villaseñor A, y Hernández Mendo A. (2004). Optimización de modelos de medida en la evaluación de programas de actividad física. Metodología de las Ciencias del Comportamiento, Suplemento 2004:427-433

Morales V, Hernández-Mendo A, y Blanco A. (2005). Evaluación de la calidad en los programas de actividad física. Psicothema 17(2):311-317

Morales V, Hernández-Mendo A, Blanco Á. (2009). Evaluación de la calidad en organizaciones deportivas: adaptación del modelo SERVQUAL. Revista de Psicología del Deporte 18:137-150

National Quality Assurance and Accreditation Committee. (2004). Law Draft. Commission of Quality and Accreditation in Education, Ministry of Higher Education, Egypt. Pardo. 2003.

Redondo JC. (1997). Ideología, política y programas deportivos municipales. Valladolid, Facultad de Ciencias Económicas y Empresariales

Redondo JC, Olivar D, \& Redondo A. (2006). El modelo EFQM de gestión de la calidad en las instalaciones deportivas. Sevilla: Wanceulen..

Rial-Boubeta J, Varela-Mallou J, Rial-Boubeta A. (2010). Modelización y medida de la Calidad Percibida en centros deportivos: la escala QSport-10. RICYDE. Revista Internacional de Ciencias del Deporte 6(18):57-73. doi:10.5232/ricyde2010.01804

Robinson L. ( 2002). Is quality management appropriate for public leisure services? Managing Leisure. $2002 ; 7: 33-40$.

Ruiz-Olalla MC. (2001). Gestión de la calidad del servicio a través de indicadores externos. Madrid: Asociación Española de Contabilidad y Administración de Empresas. 2001.

Shaf'i, H. (2006). Application Standars of Total Quality Mangement in Sport Organization Arab Society. Dar Al wafer for Publishing, Alexandria.

Papadimitriou DA, Karteroliotis K. (2000). The service quality expectations in private sport and fitness centers: a reexamination of the factor structure. Sport Market $Q$ 9:157-164

Powell TC. (1995). Total quality management as competitive advantage: a review and empirical study. Strateg Manag J 16(1):15-37

Rial-Boubeta J, Varela-Mallou J, Rial-Boubeta A. (2010). Modelización y medida de la Calidad Percibida en centros deportivos: la escala QSport-10. RICYDE. Revista Internacional de Ciencias del Deporte 6(18):57-73. doi:10.5232/ricyde2010.01804

Quesada S and Diez MD. (2002). Dirección de centros deportivos: principales funciones y habilidades del directordeportivo. Barcelona: Paidotribo. 2002.

Redondo JC, Olivard D, \& Redondo A. (2006). El modelo EFQM de gestión de la calidad en las instalaciones deportivas. Sevilla: Wanceulen.

Redondo JC. (1997). Ideología, política y programas deportivos municipales. Valladolid, Facultad de Ciencias Económicas y Empresariales 
Ruiz S. (2003). Implantación del sistema de gestión de calidad Normas ISO 9001:2000 en el Instituto de Deportes de Sevilla. Málaga: Instituto Andaluz del Deporte.

Salazar IR. (2015). Diseño de un Sistema de la Calidad Total en el ámbito deportivo. Modelo MEXD de Excelencia Deportiva. Recuperada de

http://roderic.uv.es/bitstream/handle/10550/49623/tesis\%20Modelo\%20MEXD\%20definitiva.pdf?sequence $=1$

Tsitskari E, Tsiotras D, Tsiotras G. (2006). Measuring service quality in sport services. Total Qual Manag 17(5):625-631

Salvador CM. (2005). La percepción del cliente de los elementos determinantes de la calidad del servicio universitario. Características del servicio y habilidades profesionales. Papeles del Psicólogo, 90, abrilSenlle,

Sila I. (2007). Examining the effects of contextual factors on TQM and performance through the lens of organizational theories: An empirical study. J Oper Manag 25:83-109

Van Bottenburg, van 't Hof \&Oldenboom. (1997). Good, better best:Towardsa quality policy in multiform sport sector.Amesterdam . Diopter (in Dutch)

Witcher, B.J. (1990). Total Marketing: Total Quality and Marketing Concept. The Quarterly Review of Marketing Winter, 12(5), 55-61.

Zeithaml, V.A., Parasuraman, A., and Berry, L.L. ( 1985). Problems and Strategies in services Marketing . Journal of Marketing , Vol.49, Spring pp. 33-46

Zargar SM, Faghani K, y Mahmudi G. (2011). Assessing the role of the EFQM Excellence Model in organizational viability. World Appl Sci J 14(7):987-995Sila, 2007). 